\title{
Survey for neoplasia in Macoma balthica from the Gulf of Gdansk by flow cytometry
}

\author{
K. Smolarz ${ }^{1}$, T. Renault ${ }^{2, *}$, P. Soletchnik ${ }^{3}$, M. Wolowicz ${ }^{1}$ \\ ${ }^{1}$ Laboratory of Estuarine Ecology, Institute of Oceanography, University of Gdansk, Al. Pilsudskiego 46, 81-378 Gdynia, Poland \\ ${ }^{2}$ IFREMER, Laboratoire de Génétique et Pathologique, 17390 La Tremblade, France \\ ${ }^{3}$ IFREMER, Laboratoire Conchylicole de Poitou Charentes, 17390 La Tremblade, France
}

\begin{abstract}
Using flow cytometry, 234 Macoma balthica were examined during a survey to determine frequency of neoplasia in the Gulf of Gdansk (Poland). Clams were collected in 4 locations and DNA content in gill tissue cells was determined by flow cytometry using propidium iodide staining. Cell permeabilization was induced by osmotic shock. Prevalence of neoplasia ranged from 9.6 to $26.7 \%$ depending on location. DNA content in aneuploid cells was higher than in normal dividing cells. The fluorescence value for aneuploid cells corresponded to tetraploid/pentaploid cells. Three stages of neoplasia were defined, based on the percentage of aneuploid cells determined by flow cytometry. Histopathological and cytogenetic analyses were also carried out on the same clams for comparative study. Proportions of normal and affected clams detected using flow cytometry were similar to those identified using both methods. In the present study, no clear relationship was demonstrated between prevalence of neoplasia and pollutant detection in the different sampling sites.
\end{abstract}

KEY WORDS: Gill neoplasia · Flow cytometry · Macoma balthica $\cdot$ Prevalence - Resale or republication not permitted without written consent of the publisher

\section{INTRODUCTION}

Proliferative disorders characterised by enlarged, undifferentiated cells presenting a high nucleus to cytoplasm ratio and presence of a high mitotic index have been described in 20 bivalve species (Farley 1969, Elston et al. 1990, Peters et al. 1994, Alonso et al. 2001, Villaba et al. 2001) including Macoma balthica (L.) (Elston et al. 1992, Pekkarinen 1993, Thiriot-Quiévreux \& Wolowicz 1996, 2001). In M. balthica from the Gulf of Gdansk (Baltic Sea, Poland) neoplasia was identified by the occurrence of abnormal metaphases in gill cells (Thiriot-Quiévreux \& Wolowicz 1996). Neoplasia was reported throughout the whole of the Gulf of Gdansk in 1998, with 33\% prevalence (Thiriot-Quiévreux \& Wolowicz 1996). High levels of pollution in the Gulf of Gdansk were suggested to contribute to the increased prevalence of neoplasia (Szefer et al. 1996, Sokolowski et al. 1999, Hummel et al. 2000); the precise cause of the gill neoplasia remains unknown. Carcinogens were previously described as possible contributing factors in the etiology of bivalve neoplasia (van Beneden et al. 1993, Landsberg 1996, Roy et al. 1998).
Bivalve neoplasia has been diagnosed using histology or hemocytology (Christensen et al. 1974, Mix 1983, Bert et al. 1993, Pekkarinen 1993, Villaba et al. 1997, Krishnakumar et al. 1999), DNA quantitation (Elston et al. 1990, Moore et al. 1991, Reno et al. 1994), specific antibody staining (Smolowitz \& Miosky 1986, Miosky et al. 1989) and cytogenetics (Gee et al. 1994, Thiriot-Quiévreux \& Wolowicz 1996, House et al. 1998, Thiriot-Quiévreux \& Wolowicz 2001). In the present study, flow cytometry was used to diagnose neoplasia and to define the status of ploidy of Macoma balthica populations collected in 4 locations in the Gulf of Gdansk (Baltic Sea, Poland).

\section{MATERIALS AND METHODS}

Clams. Macoma balthica (12 to $22 \mathrm{~mm}$ shell length) were collected in 2002 by dredging in the Gulf of Gdansk (Baltic Sea, Poland) at 4 locations V40, V60, H45 and PB30 (Fig. 1). Sampling sites were selected to represent different hydrological and environmental conditions. Two sites, V40 and V60, were situated in 


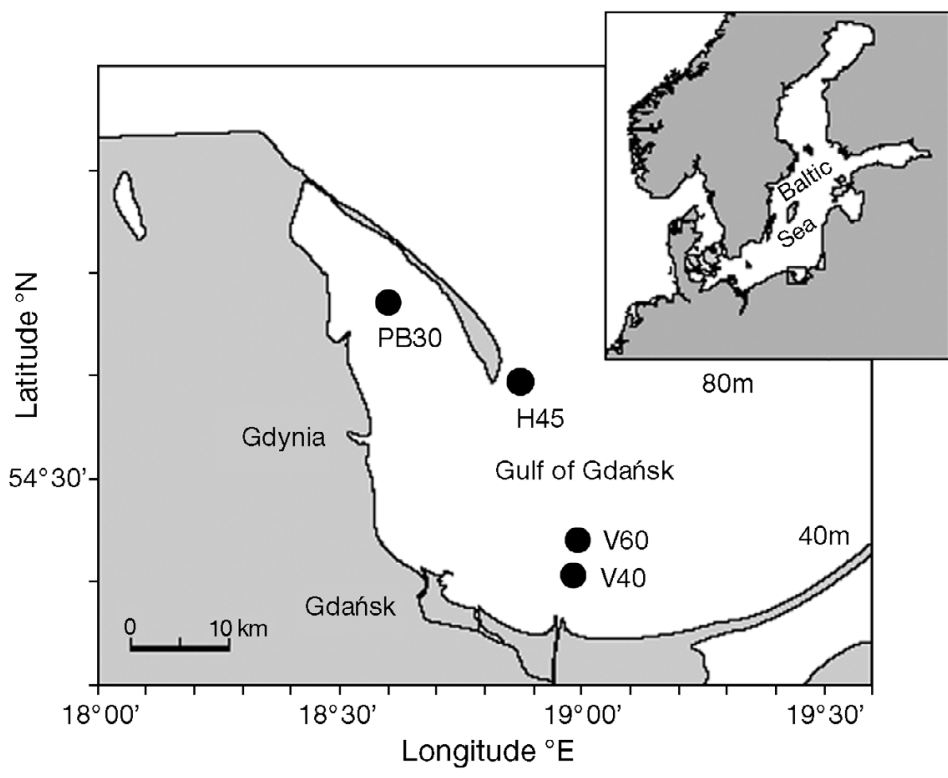

Fig. 1. Sampling stations in the Gulf of Gdansk (Baltic Sea, Poland)

the Vistula river estuary. Site H45 was situated in the deepest part of the Gulf close to the Gdansk Deep. At this site the bottom water is usually anoxic and has significant levels of hydrogen sulphide. Site PB30 was in the western part of the Gulf of Gdansk. The number for each site name designates the depth in meters. Collected $M$. balthica were brought to the IFREMER laboratory in La Tremblade (France). Before analysis, clams were incubated for $8 \mathrm{~h}$ in colchicine $(0.005 \%$ in seawater), which is an antimitotic agent. All clams were analysed using flow cytometry, histology and cytogenetics.

Flow cytometry. A protocol previously developed at the IFREMER laboratory in La Tremblade (France) (K. Smolarz et al. pers. comm.) was used to diagnose gill neoplasia. In brief, gill tissues from each individual were ground in a microtube and the resulting cell suspension was filtered through a $60 \mu \mathrm{m}$ mesh. After filtration, each sample was adjusted to $0.5 \mathrm{ml}$ with sterile distilled water and left in ice before flow cytometry analysis. The cell cycle was assessed by staining DNA with propidium iodide (PI, Interchim), at a final concentration of $50 \mathrm{ng} \mathrm{ml}^{-1}$. The incubation period was $30 \mathrm{~min}$ in the dark at $20^{\circ} \mathrm{C}$. Gill cells were analysed with an EPICS XL4 flow cytometer (Beckman Coulter). PI red fluorescence excited at $488 \mathrm{~nm}$ walvelength was collected through a $600 \mathrm{~nm}$ band pass filter. For each gill sample 3000 events were counted. Data were registered on the logarithmic scale and results were expressed as histograms of the cell fluorescence $(x-$ axis) and number of cells ( $y$-axis).
The cytometric pattern of normal clams consisted of 2 major peaks: B (G0/G1 resting cells) and C (G2/M dividing cells). Cytometric profiles of affected clams consisted of 2 major peaks B' (G0/G1 normal cells, identical to peak B) and $C^{\prime}$ (G0/G1 aneuploid cells). Two parameters were used to define ploidy in Macoma balthica populations: the percentage of cells in peaks $B, C, B^{\prime}$ and $C^{\prime}$, and the ratio between the mean fluorescence values of peaks B, C, B' and C' (K. Smolarz et al. pers. comm.). Three stages of neoplasia could be identified. Stage I was characterised by more than $10 \%$ of cells in the $C^{\prime}$ peak and mean $\mathrm{B}^{\prime} / \mathrm{B}^{\prime}+\mathrm{C}^{\prime}$ ratio at 83. Stage II consisted of more than $25 \%$ of cells in the $\mathrm{C}^{\prime}$ peak and a 0.68 mean $\mathrm{B}^{\prime} / \mathrm{B}^{\prime}+\mathrm{C}^{\prime}$ ratio. Stage III of the neoplasia was characterized by more than $40 \%$ of cells in the $\mathrm{C}^{\prime}$ peak and a mean $\mathrm{B}^{\prime} / \mathrm{B}^{\prime}+\mathrm{C}^{\prime}$ ratio at 0.49 .

Histology. Tissues were placed in Davidson's fixative for $48 \mathrm{~h}$. Samples were dehydrated through an ascending ethanol series, cleared in xylene and embedded in paraffin. Histological blocks were sectioned at $2 \mu \mathrm{m}$ thickness. Sections were stained with hematoxylin and eosin ( $\mathrm{H} \& \mathrm{E}$ ) and examined for the presence of neoplastic cells. Identified cases of neoplasia were classified from I to IV, according to Christensen et al. (1974) and Pekkarinen (1993).

Chromosome analysis. Gill samples were treated for $45 \mathrm{~min}$ in sodium citrate $(0.9 \%)$ in distilled water and fixed in a solution containing absolute ethanol and acetic acid (3:1), with 2 baths of 20 min and 2 baths of $10 \mathrm{~min}$. A slide preparation was made from tissue from each individual (Thiriot-Quiévreux \& Ayraud 1982) and stained for 8 min with Giemsa (Sigma, $4 \%$ ) in distilled water (pH 6.8). Mitosis detection under light microscopy determined the presence or absence of gill neoplasia.

Statistical analysis. Statistical analyses of cytometric peaks ( $\mathrm{B}, \mathrm{B}^{\prime}, \mathrm{C}$ and $\mathrm{C}^{\prime}$ ) including test of normality, were carried out using analysis of variance and multiple comparison test according to the least significant difference (LSD) method (Snedecor \& Cochran 1957), using Statgraphics version 3.1 software. Cytometric profile peaks together with $\mathrm{B} / \mathrm{B}+\mathrm{C}$ and $\mathrm{B}^{\prime} / \mathrm{B}^{\prime}+\mathrm{C}^{\prime}$ variables were converted into angular arc $\sin \sqrt{ }(\%$ of variable $)$ before analysis.

Table 1. Average contribution of affected Macoma balthica defined using histology, flow cytometry and genetics in the Gulf of Gdansk at 4 sampling sites.

\begin{tabular}{|lccccc|}
\hline Station & $\begin{array}{c}\text { No. clams } \\
\text { studied }\end{array}$ & \begin{tabular}{c} 
Histology \\
\cline { 3 - 5 }
\end{tabular} & $\begin{array}{c}\text { No. with neoplasia } \\
\text { Flow cytometry }\end{array}$ & Cytogenetics & $\begin{array}{c}\text { Prevalence } \\
(\%)\end{array}$ \\
\hline H45 & 30 & 8 & 8 & 8 & 26.67 \\
PB30 & 82 & 16 & 16 & 16 & 19.51 \\
V40 & 52 & 5 & 5 & 5 & 9.62 \\
V60 & 70 & 8 & 8 & 8 & 11.43 \\
Total & 234 & & 37 & & 16.08 \\
\hline
\end{tabular}


Table 2. Three different stages of neoplasia in Macoma balthica defined using flow cytometry

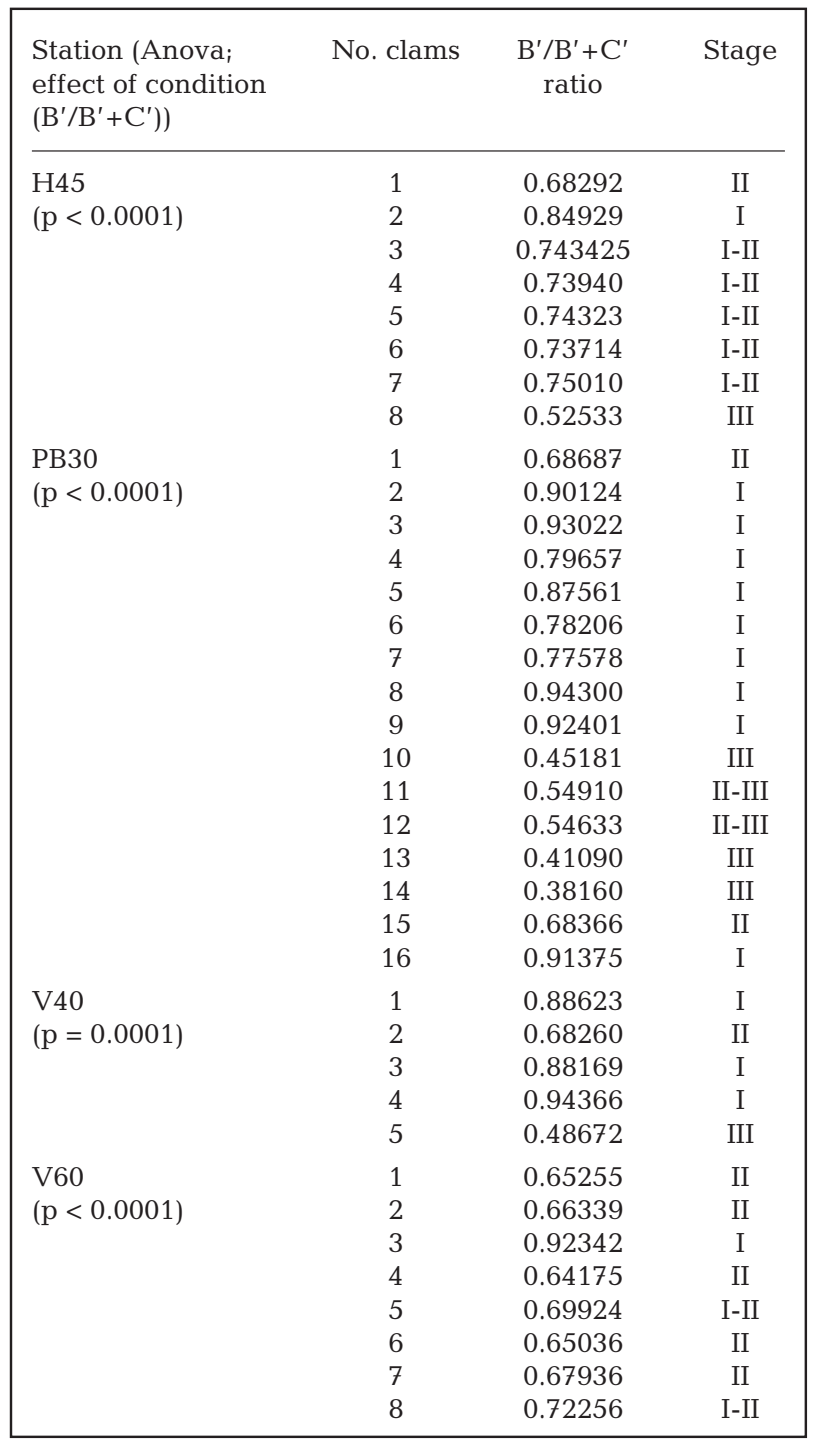

\section{RESULTS}

A total of 234 individuals from the 4 sites was analysed using flow cytometry, histology and cytogenetics. 37 animals had neoplasia (Table 1) giving an overall prevalence of $16.1 \%$. Site specific prevalence ranged from $9.6 \%$ to $26.7 \%$. The lowest prevalence occurred at site V40, the highest at H45. The 3 stages of neoplasia determined by flow cytometry were reported in these clams. Stage I of neoplasia was characterized by a major population of cells in $\mathrm{B}^{\prime}$ peak and the $\mathrm{B}^{\prime} / \mathrm{B}^{\prime}+\mathrm{C}^{\prime}$ ratio at 0.83 and was detected in 14 clams (Table 2). Nine individuals were detected in stage II (Table 2) which consisted of a lower percentage of cells in $\mathrm{B}^{\prime}$ peak and higher in $\mathrm{C}^{\prime}$ peak. The $\mathrm{B}^{\prime} / \mathrm{B}^{\prime}+\mathrm{C}^{\prime}$ ratio was 0.68. Five clams were classified in stage III (Table 2). At this stage of neoplasia, the percentage of cells in $\mathrm{C}^{\prime}$ peak was similar or higher than that in $\mathrm{B}^{\prime}$ peak and the $\mathrm{B}^{\prime} / \mathrm{B}^{\prime}+\mathrm{C}^{\prime}$ ratio was 0.49 .7 clams were classified between stages I and II. Two clams were between stages II and III; these clams were characterised by different proportions between $\mathrm{B}^{\prime}$ and $\mathrm{C}^{\prime}$ peaks.

The cytometric profiles of normal and affected clams are shown in Fig. 2a and b, respectively. The mean ratio of fluorescence values between peaks $B$, $\mathrm{B}^{\prime}, \mathrm{C}$ and $\mathrm{C}^{\prime}$ was similar at V40, V60 and H45 and consisted of $0.515 \pm 0.005$ for normal clams and $0.44 \pm$

(a)

E FL3 LOG

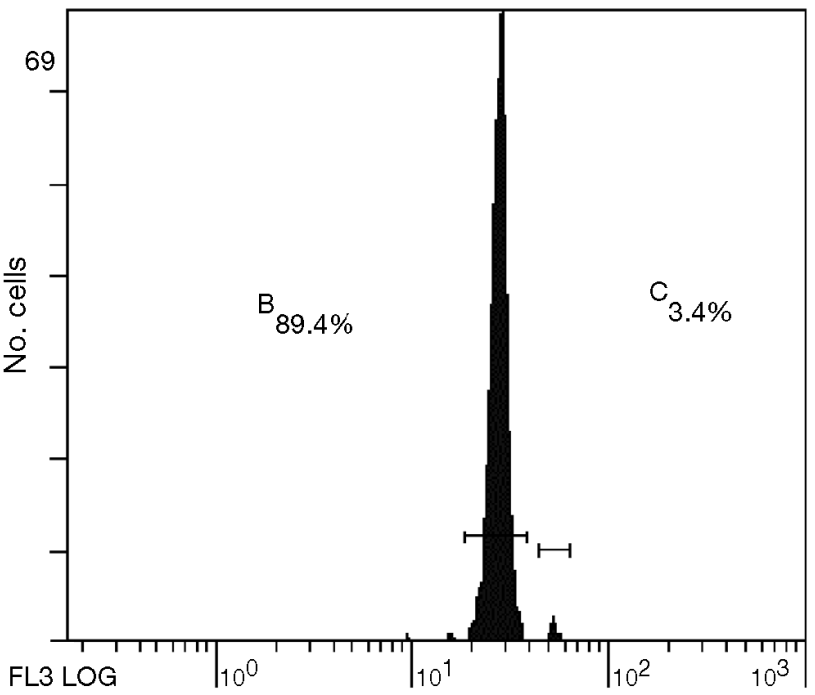

(b)

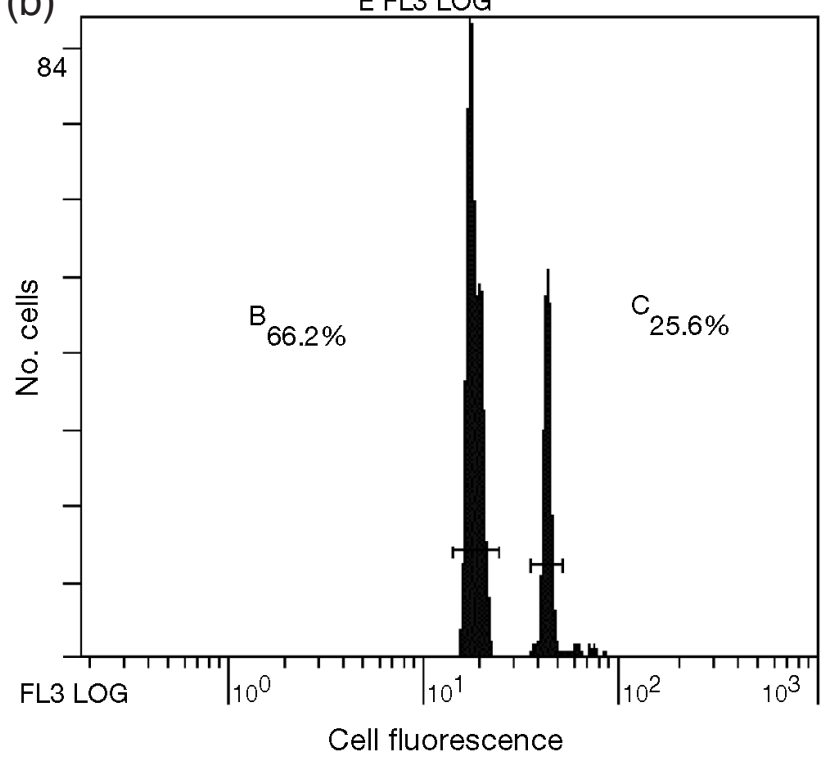

Fig. 2. Macoma balthica. Cytometry profile of (a) normal and (b) affected clams (Stn H45, stage II, clam no. 1) 
0.01 for affected clams (Fig. 3a). At PB30 the ratio of fluorescence values between peaks was the lowest and consisted of $0.49 \pm 0.005$ for normal clams and $0.41 \pm 0.01$ for affected clams (Fig. 3a). In normal clams the mean value of ratios $\mathrm{B} / \mathrm{B}+\mathrm{C}$ was similar at all sampling sites and occurred at $0.92 \pm 0.015$ (Fig. 3b). In affected Macoma balthica the lowest prevalence ratio $\left(\mathrm{B}^{\prime} / \mathrm{B}^{\prime}+\mathrm{C}^{\prime}\right)$ was noted at V60 (0.70 \pm $0.02)$ and the highest at $\mathrm{V} 40(0.78 \pm 0.03)$ (Fig. 3b). At site V60 clams at the first and second stages of neoplasia only were noted, while all stages were present at the other 3 stations (Table 2).

Histopathological and cytogenetic analysis was carried out on the same clams. The proportion of normal and affected Macoma balthica detected using flow cytometry was similar to that identified using histolog- (a)
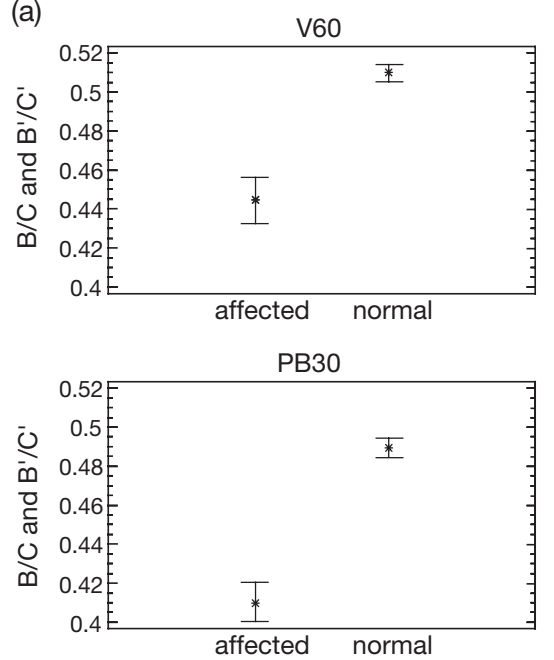

(b)
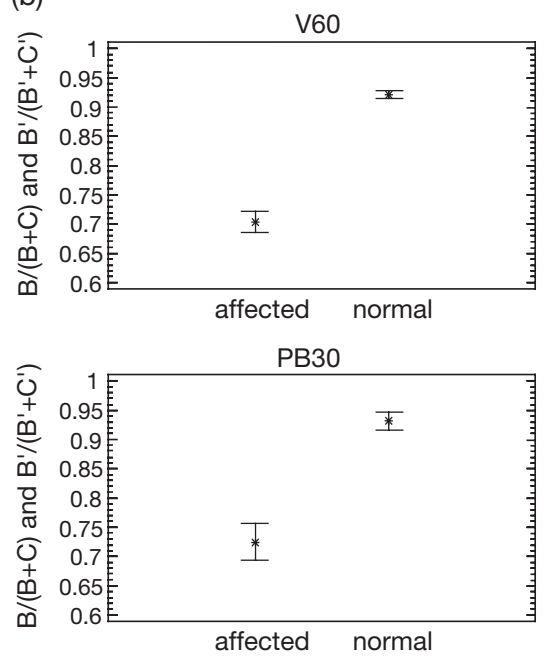
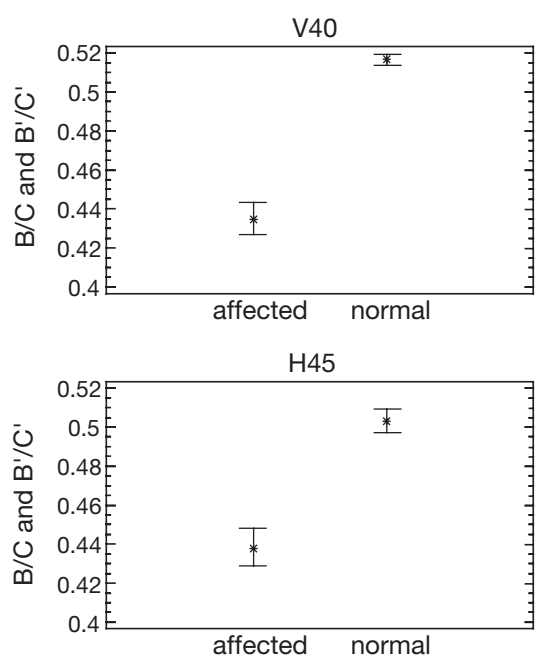

affected normal
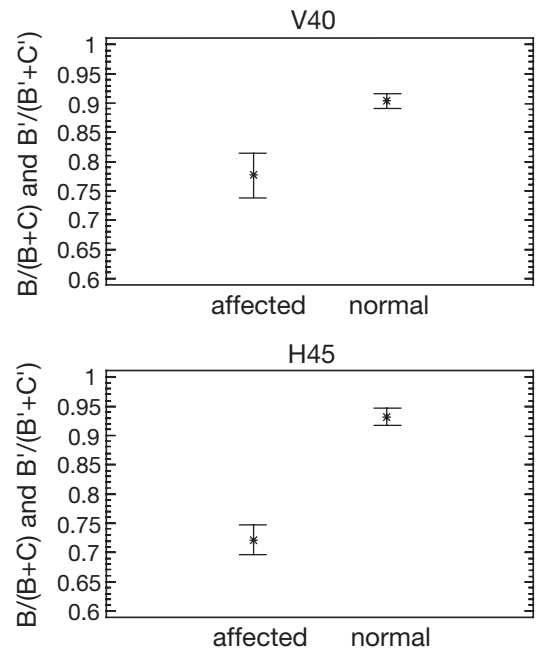

Fig. 3. Macoma balthica. (a) The ratio of fluorescence values (B/C or $\left.\mathrm{B}^{\prime} / \mathrm{C}^{\prime}\right)$ in normal and affected clams for 4 sampling stations. (b) The prevalence of peaks observed as a $B / B+C$ and $B^{\prime} / B^{\prime}+C^{\prime}$ ratio $(\mathrm{p}<0.0001)$ ical analysis and cytogenetics (Table 1). Neoplastic cells were detected on histological sections in gills and other organs including mantle and gonads. Heavily affected individuals showed infiltration of neoplastic cells in all tissues and mitotic figures (Fig. 4).

\section{DISCUSSION}

The fluorescence value (DNA content) measured by flow cytometry in aneuploid cells (peak $C^{\prime}$ ) mainly corresponded to tetraploid/pentaploid cells (2.36 diploid value). Chromosome number scored in abnormal mitosis using chromosome analysis (2.37 diploid value) was similar to the value observed using flow cytometry. The number of chromosomes in diploid Macoma balthica clams is 38. Chromosome number scored in abnormal mitosis ranged from 59 to 109 with a mean of 84 (Thiriot-Quiévreux \& Wolowicz 1996, 2001). The number of metaphase chromosomes of neoplastic cells on chromosome preparation coincided with DNA content determined by flow cytometry in affected clams. Elston et al. (1990) and Moore et al. (1991) reported that systemic neoplasia exists in 2 major forms characterized by the occurrence of tetraploid and pentaploid cells, respectively. The existence of alternate forms could also be observed in $M$. balthica. In clams collected in the Gulf of Gdansk, pentaploid cells were predominant. Three different stages of neoplasia were also identified based on the $\mathrm{B}^{\prime} / \mathrm{B}^{\prime}+\mathrm{C}^{\prime}$ ratio. Clams presenting a $\mathrm{B}^{\prime} / \mathrm{B}^{\prime}+\mathrm{C}^{\prime}$ ratio of 0.8 were characterized by a low percentage of abnormal cells. Lower values of $\mathrm{B}^{\prime} / \mathrm{B}^{\prime}+\mathrm{C}^{\prime}$ ratio were associated with higher occurrence of neoplasia. $M$. balthica with $\mathrm{B}^{\prime} / \mathrm{B}^{\prime}+\mathrm{C}^{\prime}$ ratio of 0.5 showed widespread proliferation of neoplastic cells in all tissues.

Thiriot-Quiévreux \& Wolowicz (1996) reported chromosomal abnormalities related to neoplasia in Macoma balthica clams from the Gulf of Gdansk. Among 47 specimens studied, 6 presented enlarged nuclei and abnormal mitosis while 7 specimens showed intermediate features (Thiriot-Quiévreux \& Wolowicz 1996). Moreover, 33\% of clam populations from the Gulf of Gdansk were affected by neoplasia (Thiriot-Quiévreux \& Wolowicz 1996, 


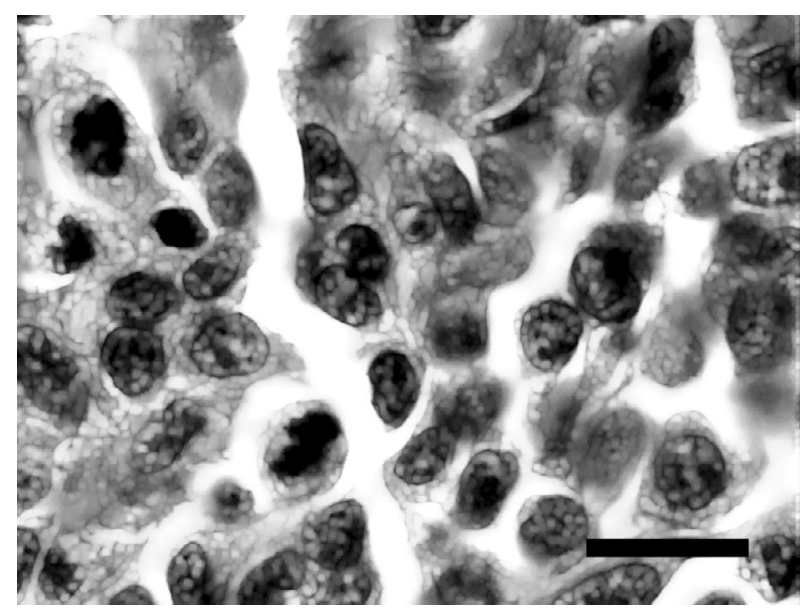

Fig. 4. Macoma balthica. Histological section of affected clam showing neoplastic cells with enlarged nuclei and 2 mitotic figures in gills. $\mathrm{H} \& \mathrm{E}$, scale bar $=10 \mu \mathrm{m}$

2001). In the present study, $16.1 \%$ were neoplastic. The prevalence of neoplasia varied from $9.6 \%$ (V40) to $26.7 \%$ (H45). The highest percentage of affected clams occurred at the location H45, while the lowest occurred in Vistula estuary (V40). M. balthica is the only bivalve species in the Gulf of Gdańsk that can occupy habitats of a depth of up to 90 m (Janas \& Szaniawska 1996). Station H45 is located on the steep slope of the Hel Peninsula where deeper waters from the Baltic Sea encounter water inflows from the North Sea. The water inflow from the North Sea modifies environmental conditions in the Gulf of Gdańsk increasing salinity and reducing temperature, leading to a thermo-halocline stratification (Nowacki et al. 1993, Andrulewicz 1996). However, the inflow of saline and denser waters from the North Sea has been restricted over the past few years. Hypoxia and anoxia have occurred in stagnant bottom waters accompanied by high levels of hydrogen sulphide in the deeper part of the Gulf (Janas \& Szaniawska 1996). Clams may therefore be subject to adverse conditions that may induce stress. In laboratory conditions, stress induced by emersion reduces or blocks the uptake and distribution of oxygen in $M$. balthica which then switch to anaerobic metabolism, together with diffusion of sulphide into the mitochondrion and evoke tissue anoxia by blocking cytochrome a3 (de Zwann \& Babarro 2000).

Pollutants may also be involved in neoplasia occurrence in Macoma balthica. Falandysz et al. (1996, 1997, 1998) reported that polychlorinated napthalenes (PCNs) were present in different fish species and other organisms collected from the southwestern part of the Gulf of Gdańsk. Highest concentrations of PCBs were noted in the neighbourhood of sites H45 and V60 (Konat \& Kowalewska 2001). The sampling site V60 at
$60 \mathrm{~m}$ depth was located in the Vistula estuary, beneath the thermocline and halocline. The Vistula river transports a variety of contaminants including nitrogen, heavy metals and organic compounds to the estuary (Andrulewicz 1996, Sokolowski et al. 1999, 2001). A direct relationship between metallic pollutants in sediment and physiology has been observed in $M$. balthica from the Vistula estuary (Sokolowski et al. 1999, Hummel et al. 2000). The highest concentration of $\mathrm{Cu}, \mathrm{Zn}$, $\mathrm{Pb}, \mathrm{Cd}$ and $\mathrm{Ag}$ in sediments occurred near the mouths of the Vistula River, Puck Bay and Gdansk Bay (Glasby \& Szefer 1998). Chemical compounds deposited in the sea bottom may act as carcinogenic agents. Although the sampling site V40 is also located in the Vistula estuary, the lowest prevalence of neoplasia was reported at this site. Moreover, sediments from nearly all sites in the Gulf of Gdansk demonstrated acute toxicity (M. Wolowicz et al. pers. comm.). Pollutants are not able to induce neaplasia in $M$. balthica alone. We suggest that several environmental factors may initiate and sustain neoplasia in the clam habitats.

Acknowledgements. This study was supported by funds from the Marie Curie Host Fellowships (no QLK5-CT-2001-60036) provided by the European Commission. We would like to thank P. Goulletquer for allowing the work at the IFREMER station in La Tremblade (CharenteMaritime, France). We thank Dr. S. Webb (Cawtron Institute, Nelson, New Zealand) for improving the English of this manuscript and R. Lasota for collecting samples.

\section{LITERATURE CITED}

Alonso A, Suarez P, Alvarez C, San Juan F, Molist P (2001) Structural study of a possible neoplasia detected in Mytilus galloprovincialis collected from the Ria of Vigo (NW Spain). Dis Aquat Org 47:73-79

Andrulewicz E (1996) The regional characteristics of the Gdansk basin. Ocean Stud 1-2:11-16

Bert TM, Hesselman DM, Arnold WS, Moore WS, Cruz-Lopez H, Marelli DC (1993) High frequency of gonadal neoplasia in a hard clam (Mercenaria spp.) hybrid zone. Mar Biol 117:97-104

Christensen DJ, Farley CA, Kern FG (1974) Epizootic neoplasms in the clam Macoma balthica (L.) from Chesapeake Bay. J Natl Cancer Inst 52:1739-1749

De Zwann A, Babarro JMF (2000) Studies on the causes of mortality of the estuarine bivavle Macoma balthica under condition of (near) anoxia. Mar Biol 138:1021-1028

Elston RA, Drum AS, Allen SK Jr (1990) Progressive development of circulating polyploid cells in Mytilus with hemic neoplasia. Dis Aquat Org 8:51-59

Elston RA, Moore JD, Brooks K (1992) Disseminated neoplasia of bivalve molluscs. Rev Aquat Sci 65:405-466

Falandysz J, Strandberg L, Bergqvist PA, Kulp SE, Strandberg B, Rappe C (1996) Polychlorinated naphthalenes in sediments and biota from the Gdansk Basin, Baltic Sea. Environ Sci Technol 30:3266-3274

Falandysz J, Strandberg L, Bergqvist PA, Strandberg B, Rappe C (1997) Spatial distribution and bioaccumulation 
of polychlorinated naphthalenes (PCBs) in mussel and fishes from the Gulf of Gdansk, Baltic Sea. Sci Total Environ 203:93-104

Falandysz J, Strandberg L, Strandberg B, Rappe C (1998) Polychlorinated naphthalenes in 3-spined stickleback Gasterosteus aculeatus from the Gulf of Gdansk. Chemosphere 37:2473-2487

Farley CA (1969) Probable neoplastic disease of the hematopoietic system in oysters, Crassostrea virginica and $C$. gigas. Natl Cancer Inst Monogr 31:541-555

Gee A, Specht JM, Kerk D, Moore JD, Drum AS, Elston RA (1994) Disseminated neoplastic cells in Mytilus trossulus: verification of host species origin by 16S-like rRNA sequence comparison. Mol Mar Biol Biot 3:7-12

Glasby GP, Szefer P (1998) Marine pollution in Gdansk Bay, Puck Bay and the Vistula Lagoon, Poland: an overview. Appl Geochem. 212:49-57

House ML, Kim CH, Reno PW (1998) Soft shell clams Mya arenaria with disseminated neoplasia demonstrate reverse transcriptase activity. Dis Aquat Org 34:187-192

Hummel H, Sokolowski A, Bogaards R, Wolowicz M (2000) Ecophysiological and genetic traits of the clam Macoma balthica in the Baltic: differences between populations in the Gulf of Gdansk due to acclimatization or genetic adaptation? Inter Rev Hydrobiol 85:621-637

Janas U, Szaniawska A (1996) Influence of hydrogen sulphide on macrofaunal biodiversity in the Gulf of Gdansk. Oceanologia 38:127-142

Konat J, Kowalewska G (2001) Polychlorinated biphenyls (PCBs) in sediments of the southern Baltic Sea - trends and fate. Sci Total Environ 280:1-15

Krishnakunar PK, Casillas E, Snider RG, Kagley AN, Varanasi U (1999) Environmental contaminants and the prevalence of hemic neoplasia (leukemia) in the common mussel (Mytilus edulis complex) from Puget Sound, Washington, USA. J Invertebr Pathol 73:135-146

Landsberg JH (1996) Neoplasia and biotoxin in bivalves: is there a connection? J Shellfish Res 15:203-230

Miosky LD, Smolowitz RM, Reinisch CL (1989) Leukemia cell specific protein of the bivalve mollusc Mya arenaria. J Invertebr Pathol 53:32-40

Mix MC (1983) Haemic neoplasms of bay mussels, Mytilus edulis, from Oregon: occurrence, prevalence, seasonality and histopathological progression. J Fish Dis 6:239-248

Moore JD, Elston RA, Drum AS, Wilkinson MT (1991) Alternate pathogenesis of systemic neoplasia in the bivalve mollusc Mytilus. J Invertebr Pathol 58:231-243

Nowacki J, Kowalewski M, Krezel A (1993) Long-term trends of concentration of nitrates, phosphates and oxygen in the Gulf of Gdansk. Mar Pollut 3:123-130

Pekkarinen M (1993) Neoplastic diseases in the Baltic

Editorial responsibility: Albert Sparks, Seattle, Washington, USA
Macoma balthica (Bivalvia) off the Finnish Coast. J Invertebr Pathol 61:138-146

Peters EC, Yevich PP, Harshbarger JC, Zaroogian GE (1994) Comparative histopathology of gonadal neoplasms in marine bivalve molluscs. Dis Aquat Org 20:59-76

Reno PW, House M, Illingworth A (1994) Flow cytometric and chromosome analysis of softshell clams, Mya arenaria, with disseminated neoplasia. J Invertebr Pathol 64: 163-172

Roy D, Colerangle JB, Kamleshwar PS (1998) Is exposure to environmental or industrial endocrine disrupting estrogen-like chemicals able to cause genomic instability? Front Biosci 3:913-921

Smolowitz RM, Miosky LD (1986) Indirect peroxidase staining using monoclonal antibodies specific for Mya arenaria neoplastic cells. J. Invertebr Pathol 48:139-145

Snedecor GW, Cochran WG (1957) Statistical methods. Ed Iowa State University Press,Ames, IA

Sokolowski A, Wolowicz M, Hummel H, Bogaards R (1999) Physiological responses of Macoma balthica (L.) to copper pollution in the Baltic. Oceanol Acta 22:431-439

Sokolowski A, Wolowicz M, Hummel H (2001) Distribution of dissolved and labile particulate trace metals in the overlying bottom water in the Vistula River plume (Southern Baltic Sea). Mar Pollut Bull 10:967-980

Szefer P, Szefer K, Glasby GP, Pempkowiak J, Kaliszan R (1996) Heavy metal pollution in surficial marine sediments from the Gulf of Gdansk and the Southern Baltic Sea off Poland. J Environ Sci Health 31A:2723-2754

Thiriot-Quiévreux C, Ayraud N (1982) Les caryotypes de quelques espèces de bivalves et gastéropodes marins. Mar Biol 70:165-172

Thiriot-Quiévreux C, Wolowicz M (1996) Etude caryologique d'une néoplasie branchiale chez Macoma balthica (Mollusca, Bivalvia). C R Acad Sci Paris 319:887-892

Thiriot-Quiévreux C, Wolowicz M (2001) Chromosomal study of spatial variation of the prevalence of a gill neoplasia in Macoma balthica (L.) from the Gulf of Gdansk (Baltic Sea). Ophelia 54:75-81

Van Beneden RJ, Gardner GR, Blake NJ, Blair DG (1993) Implication of the presence of transforming genes in gonadal tumors in 2 bivalve mollusk species. J Cancer Res 53:2976-2979

Villalba A, Mourelle SG, Carballal MJ, Lopez C (1997) Symbionts and diseases of farmed mussels Mytilus galloprovincialis throughout the culture process in the Rias of Galicia (NW Spain). Dis Aquat Org 31:127-139

Villalba A, Carballal MJ, Lopez C (2001) Disseminated neoplasia and large foci indicating heavy haemocytic infiltration in cockles Cerastoderma edule from Galicia (NW Spain). Dis Aquat Org 46:213-216

Submitted: February 11, 2004; Accepted: April 18, 2005 Proofs received from author(s): August 3, 2005 